\title{
Application of $\beta$-aminobutyric Acid and Spermidine Raise Drought Tolerance and Alleviate Oxidative Stress in Potted Chrysanthemum
}

\author{
Ragia M. Mazrou \\ Horticulture Department, Faculty of Agriculture, Menoufia University, Shibin El-Kom
}

\begin{abstract}
Potted chrysanthemum is an important flower crop due to its economic value as a commercial pot ornamental plant. Chrysanthemum growth and development is drastically restricted by water deficit and the available information about water stress alleviation in chrysanthemum is very limited. Although $\beta$-aminobutyric acid (BABA) and spermidine (Spd) are involved in drought tolerance, there is no reports about their applications on potted chrysanthemum. This experiment was conducted, therefore, to study the impact of BABA or Spd application on drought tolerance of potted chrysanthemum. Two water levels were used in this experiment i.e. $100 \% \mathrm{FC}$ as well-watered treatment and $50 \% \mathrm{FC}$ as drought stress treatment. BABA and Spd were each foliar applied at 0.2 or $0.4 \mathrm{mM}$ while untreated plants were sprayed with distilled water. Foliar application with BABA or Spd enhanced the growth characters, flower characters, relative water content (RWC), chlorophyll and proline contents of potted chrysanthemum under drought stress. Treatment of BABA or Spd reduced the malondialdehyde (MDA) content, $\mathrm{H}_{2} \mathrm{O}_{2}$ production and therefore maintained the membrane integrity in drought stressed plants. Additionally, the activities of catalase (CAT) and peroxidaes (POX) enzymes were improved due to BABA or Spd foliar application in drought stressed plants. The current results suggest that BABA and Spd were implicated in drought stress adaptation of potted chrysanthemum through reducing lipid peroxidation, retaining the cell membrane stability and motivating the antioxidant system.
\end{abstract}

Key words: Drought, Chlorophyll, Proline, Lipid peroxidation, Antioxidant enzymes

\section{INTRODUCTION}

Chrysanthemum (Dendranthema grandiflorum kitam.) which belongs to Asteraceae family, is very popular flower crop that has an economical value in floral industry as one of the foremost commercial pot ornamentals with a great deal of market expression (Hassan and Schmidt, 2004). Unfortunately, the growth and flowering of chrysanthemum is restricted by water deficit therefore, improving the drought tolerance is very important for a high-quality supply of pot chrysanthemum plants. Recently, drought is a main task to sustainable agriculture worldwide and it considers a prime abiotic stress which adversely affects the growth and production (Hassan et al., 2018). Drought leads to some physiological changes including cell turgor loss (Ali and Hassan, 2019) and over production of reactive oxygen species (ROS) that caused lipid peroxidation observed by higher MDA level (Talaat et al., 2015).

Plants can mitigate the damage of water stress through several physiological modifications including motivation the antioxidant machinary to detoxify ROS (Arbona and Gómez-Cadenas, 2008) and accumulation of compatible solutes that caused osmotic adjustment and the maintenance of cell turgor (Marcinska et al., 2013). Correlation between antioxidant enzyme activation and tolerance of water deficit has been observed (Ali and Hassan, 2017). There are scarce efforts to mitigate environmental stresses in chrysanthemum by breeding programs, but limited successes have been described (He et al., 2018). Improving the drought stress tolerance in this important flower crop by applying several exogenous of treatments is therefore imperative.

$\beta$-aminobutyric acid (BABA) is a, synthetic, non-protein amino acid and its natural occurrence is scarce (Mayer et al. 2006). BABA enhanced the plant tolerance versus abiotic stresses like salt and drought (Zhong et al., 2014). BABA potentiates the natural defense against environmental stresses, however its accurate mode of action in plants is yet unidentified (Vijayakumari et al., 2016). Application of BABA enhanced proline content and activity of antioxidant enzymes in rice under stress (Das et al., 2016), increased carbohydrates and proline contents, and induced osmotic potential reduction in flax (Quéro et al., 2015). BABA treatment considerably reduced MDA level and increased guaiacol peroxidase and superoxide dismutase enzyme activities (Jisha and Puthur, 2016). Although the impact of BABA on increasing the tolerance of abiotic stress in several crops has been observed, there are no reports on potted flowering plants including chrysanthemum. To our knowledge, no reports is available about how BABA regulates physiological/biochemical processes in pot chrysanthemum grown under drought.

Martin-Tanguy (2001) reported that polyamines including spermidine (Spd) are aliphatic amines and polycationic that play significant functions in plant growth. Moreover, they regulate plant stress 
alleviation through osmotic adjustment, membrane integrity improving (Takahashi and Kakehi, 2009) and free radicals scavenging (Roychoudhury et al., 2011). It has been observed that polyamines are involved in tolerance of water stress (Kubis' et al., 2014, Li et al., 2015 and Sánchez-Rodríguez et al., 2016). Several reports indicated that water stress elevates the biosynthesis of polyamines (Yang et al., 2007 and Kubis', 2008). Hence, Groppa and Benavides (2008) suggested that Spd may be involved in drought tolerance mechanism. Moreover, Spd is implicated in the growth (Pottosin et al., 2014) and tolerance of drought (Li et al., 2015 and Hassan et al., 2018).

Foliar application with Spd ameliorated the adverse effects of water stress by reducing ROS and MDA levels and promoting the antioxidants ( $\mathrm{Li}$ et al., 2015). The membrane damage and MDA level were increased under drought stress, however Spd application effectively reduced lipid peroxidation, the membrane damage and elevated the proline accumulation (Kubis' et al., 2014). A higher content of Spd motivated the antioxidant machinery observed by lower ROS production and higher CAT and SOD enzyme activities that improved the dehydration tolerance (Sánchez-Rodríguez et al., 2016). Additionally, $\mathrm{Xu}$ et al., (2011) observed that Spd treatment decreased both MDA and ROS production which reduced the plasma membrane damage. Although Spd improves several abiotic stresses tolerance in several crops, the available information concerning Spd effects on potted flowering plants including chrysanthemum is scarce. Therefore, this investigation is an attempt to mitigate the drought stress in potted chrysanthemum using BABA or Spd applications.

\section{MATERIALS AND METHODS}

\section{Soil preparation and cultivation}

Two pot experiments were carried out at the greenhouse area of Faculty of Agriculture, Menoufia University, Shibin El-Kom (30॰33'24.8' N $\left.31^{\circ} 00^{\prime} 51.3^{\prime \prime E}\right)$ during 2017 and 2018 seasons. Rooted cuttings of Dendranthema grandiflorum kitam.. cv. "White Reagan" were obtained from commercial grower at the 1st of August and transported to the greenhouse and transplanted into $20 \mathrm{~cm}$ pots $(1.6 \mathrm{~L})$ with three plants as commonly used in greenhouse production (Ali and Hassan, 2016). The pots were filled with substrate consists of sand:peat:perlite in a proportion of $1: 1: 1$ (v/v/v).

\section{Drought stress treatments}

After transplanting, the plants were divided into two groups and treated with two water regimes: the first group was well watered (exposed to100\% FC) as treatment and the second one was drought stressed (exposed to $50 \%$ of FC). The pots were weighted daily to control the soil water content.

\section{BABA and Spd treatments}

Each group of water regimes was foliar sprayed with 0.2 and $0.4 \mathrm{mM}$ from BABA or Spd. The plants were weekly sprayed till flowering stage. A surfactant of Tween $80(0.5 \% \mathrm{v} / \mathrm{v})$ was added before spraying. Distilled water with the same surfactant was used for control plants spraying. The pots were arranged in two-way factorial experiment and a completely randomize design was used (Snedecor and Cochran, 1980). Four replicates of each treatment were conducted with three pots each.

\section{Growth and flowers parameters}

At flowering stage, plant height $(\mathrm{cm})$, stem diameter $(\mathrm{cm})$, branch number per plant were recorded. To determine leaf area $\left(\mathrm{cm}^{2}\right)$, the digital image analysis described by Matthew et al., (2002) was used to measure the blade area. Days to the first flower (anthesis), flower number/plant, flower diameter $(\mathrm{cm})$ and shelf life of whole pot (days) were assessed. Shelf life was the days between opening of 2-3 flowers till wilting more than $50 \%$ of flowers.

\section{Relative water content (RWC)}

Samples for the subsequent physiological and biochemical investigations were collected at flowering stage. Leaf midday RWC was investigated by Weatherley (1950) method following the equation: $\left(\mathrm{W}_{\text {fresh }}-\mathrm{W}_{\text {dry }}\right) /\left(\mathrm{W}_{\text {turgid }}\right.$ $\left.\mathrm{W}_{\text {dry }}\right) \times 100$ where $\mathrm{W}_{\text {fresh }}$ is the sample fresh weight, $\mathrm{W}_{\text {turgid }}$ is the turgid weight of sample after saturation in distilled water for $24 \mathrm{~h}$ at $4{ }^{\circ} \mathrm{C}$, and $\mathrm{W}_{\text {dry }}$ is the oven-dry weight of the sample (at $70{ }^{\circ} \mathrm{C}$ for $48 \mathrm{~h}$ ).

\section{Chlorophyll determination}

Leaf chlorophyll content was determined using Metzner et al., (1965) method after sample extraction in acetone then the extract was spectrophotometrically investigated. The total chlorophyll was recorded as $\mathrm{mg} \mathrm{g}^{-1}$ fresh weight.

\section{Proline analysis}

Free proline content was investigated according to Bates et al., (1973). The absorbance at $520 \mathrm{~nm}$ was spectrophotometrically determined with toluene as the blank. The proline content was calculated and presented as $\mu \mathrm{mol} \mathrm{g}^{-1} \mathrm{FW}$ based on a standard curve.

\section{Membrane stability index (MSI)}

Ions leakage was investigated according to Sairam et al., (1997) to assess the membrane stability using a conductivity meter.

Malondialdehyde (MDA) content

MDA content was determined as an indicator for lipid peroxidation according to Hodges et al., (1999).

Determination of hydrogen peroxide $\left(\mathrm{H}_{2} \mathrm{O}_{2}\right)$

$\mathrm{H}_{2} \mathrm{O}_{2}$ content was investigated by the method of Patterson et al., (1984). Samples were homogenized with chilled acetone $100 \%$ and centrifuged at 
$12,000 \mathrm{~g}$ for $10 \mathrm{~min}$ at $4{ }^{\circ} \mathrm{C}$. The absorbance was observed at $412 \mathrm{~nm}$ and calibrated with a standard curve using different concentrations of $\mathrm{H}_{2} \mathrm{O}_{2}$.

\section{Antioxidant enzyme assays}

The method described by Bradford (1976) was used for assessment of soluble protein for enzyme extract. The activity of CAT (EC 1.11.1.6) was spectrophotometrically assessed as described by Clairbone (1985) by following the $\mathrm{H}_{2} \mathrm{O}_{2}$ disappearance at $240 \mathrm{~nm}$. The level of CAT activity

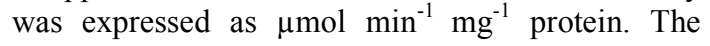
activity of POX (EC 1.11.1.7) was evaluated according to Shanon et al., (1966). The absorbance level was observed by spectrophotometer at $470 \mathrm{~nm}$ and the enzyme activity level was expressed as $\mu$ mol min ${ }^{-1} \mathrm{mg}^{-1}$ protein.

\section{Statistical analysis}

This experiment was duplicated, and combined analysis of pooled data was conducted for the two seasons. To analyze data, it was subjected to ANOVA by SPSS program (13.3). Statistical differences between means were investigated by Tukey-Kramer's multiple range test at $P=0.05$. Each value is the mean $\pm \mathrm{SE}$ of the two experiments $(n=$ 8).

\section{Growth parameters}

\section{RESUITS}

The growth of potted chrysanthemum was adversely affected due to drought stress; however foliar application of BABA or Spd improved the plant growth under drought. Plant height, branch number, stem diameter and leaf area were markedly reduced by drought stress treatment (50\% FC), while BABA and Spd applications enhanced these characters (Table 1). Under $100 \%$ FC the differences between BABA or Spd and untreated control were non-significant however, the treatment of Spd at $0.4 \mathrm{mM}$ recorded the best results in this respect.

\section{Flower characters}

Data obtained showed that applying $50 \%$ FC considerably decreased the time to anthesis and hence accelerated the first flower appearance compared to $100 \% \mathrm{FC}$ treatment. Additionally, the time to anthesis was not significantly affected by BABA or Spd treatments under $100 \%$ FC, however they increased the time to anthesis in water stressed plants compared to the control. Flower number/ plant, flower diameter and the pot shelf life were significantly reduced by drought stress treatment (50 $\%$ FC), while BABA and Spd applications enhanced these flower characters. The treatment of Spd at 0.4 $\mathrm{mM}$ recorded the best results in this respect (Table 2). Under $50 \% \mathrm{FC}$, the pot shelf life was extended by 57.64 and $54.62 \%$ when plants treated by 0.4 $\mathrm{mM}$ of Spd or BABA, respectively.

\section{Relative water content (RWC)}

In well-watered plants (100\% FC), a slight increase in RWC was observed as a result of BABA or Spd treatments. Otherwise, RWC was significantly reduced under $50 \%$ FC treatment however, foliar application with BABA or $\mathrm{Spd}$ improved the RWC in drought stressed plants compared to non-stressed plants (Fig. 1A). The treatment of Spd at $0.4 \mathrm{mM}$ maintained the RWC at higher level relative to the other treatments.

\section{Total Chlorophyll content}

It is clear from data in Fig. (1B) that the total chlorophyll in potted chrysanthemum leaves was considerably decreased in water stressed plants $(50$ $\%$ FC) compared to non-stressed plants (100\% FC). However, foliar application with BABA or Spd significantly retarded this reduction under drought. The best results were observed by applying Spd at $0.4 \mathrm{mM}$. Otherwise, under $100 \%$ FC the differences between BABA and Spd were not significant.

Table 1: Effects of foliar application with $\beta$-aminobutyric acid (BABA) and spermidine (Spd) on plant height, branch number, stem diameter and leaf area of potted chrysanthemum grown under $100 \%$ FC or $50 \%$ FC

\begin{tabular}{|c|c|c|c|c|c|}
\hline \multicolumn{2}{|c|}{ Treatments } & $\begin{array}{c}\text { Plant height } \\
(\mathrm{cm})\end{array}$ & Branch number & $\begin{array}{l}\text { Stem diameter } \\
(\mathrm{cm})\end{array}$ & $\begin{array}{c}\text { Leaf area } \\
\left(\mathrm{cm}^{2}\right)\end{array}$ \\
\hline \multirow{5}{*}{$100 \% \mathrm{FC}$} & Control & $36.84 \pm 0.24 b$ & $5.67 \pm 0.11 d$ & $0.46 \pm 0.03 b$ & $7.33 \pm 0.03 b$ \\
\hline & $0.2 \mathrm{mM}$ BABA & $36.87 \pm 0.21 \mathrm{~b}$ & $7.15 \pm 0.13 c$ & $0.47 \pm 0.05 b$ & $7.47 \pm 0.02 b$ \\
\hline & $0.4 \mathrm{mM}$ BABA & $37.11 \pm 0.43 \mathrm{ab}$ & $7.67 \pm 0.16 b$ & $0.46 \pm 0.04 b$ & $7.94 \pm 0.04 \mathrm{ab}$ \\
\hline & $0.2 \mathrm{mM} \mathrm{Spd}$ & $37.23 \pm 0.19 \mathrm{ab}$ & $7.97 \pm 0.19 \mathrm{ab}$ & $0.50 \pm 0.06 \mathrm{a}$ & $7.56 \pm 0.05 b$ \\
\hline & $0.4 \mathrm{mM} \mathrm{Spd}$ & $38.58 \pm 0.17 \mathrm{a}$ & $8.33 \pm 0.14 a$ & $0.52 \pm 0.04 \mathrm{a}$ & $8.22 \pm 0.06 \mathrm{a}$ \\
\hline \multirow{5}{*}{$50 \% \mathrm{FC}$} & Control & $22.26 \pm 0.22 f$ & $4.36 \pm 0.18 \mathrm{e}$ & $0.33 \pm 0.04 \mathrm{e}$ & $4.73 \pm 0.05 \mathrm{e}$ \\
\hline & $0.2 \mathrm{mM}$ BABA & $29.48 \pm 0.26 \mathrm{e}$ & $6.28 \pm 0.15 \mathrm{c}$ & $0.38 \pm 0.03 \mathrm{~d}$ & $5.78 \pm 0.03 \mathrm{~d}$ \\
\hline & $0.4 \mathrm{mM}$ BABA & $31.67 \pm 0.21 \mathrm{~d}$ & $6.89 \pm 0.12 \mathrm{c}$ & $0.42 \pm 0.05 \mathrm{c}$ & $6.28 \pm 0.04 c$ \\
\hline & $0.2 \mathrm{mM} \mathrm{Spd}$ & $31.33 \pm 0.14 \mathrm{~d}$ & $6.67 \pm 0.14 \mathrm{c}$ & $0.43 \pm 0.02 \mathrm{c}$ & $6.33 \pm 0.02 \mathrm{c}$ \\
\hline & $0.4 \mathrm{mM} \mathrm{Spd}$ & $33.78 \pm 0.27 \mathrm{c}$ & $7.49 \pm 0.16 b$ & $0.45 \pm 0.0 \mathrm{bc}$ & $7.15 \pm 0.05 b$ \\
\hline
\end{tabular}

The values (mean \pm S.E.) are the average of two independent experiments $(n=8)$. Means within a column had different letters are significantly differ for each other according to Tukey-Kramer's multiple range test at $P=0.05$. 
Table 2: Effects of foliar application with $\beta$-aminobutyric acid (BABA) and spermidine (Spd) on flower characters and shelf life of potted chrysanthemum grown under $100 \%$ FC or $50 \%$ F

\begin{tabular}{|c|c|c|c|c|c|}
\hline Treatm & ents & $\begin{array}{c}\text { Time to anthesis } \\
\text { (days) }\end{array}$ & $\begin{array}{c}\text { Flower number } \\
\text { (plant) }\end{array}$ & $\begin{array}{l}\text { Flower diameter } \\
(\mathbf{c m})\end{array}$ & $\begin{array}{l}\text { Shelf life } \\
\text { (days) }\end{array}$ \\
\hline \multirow{5}{*}{$\begin{array}{c}100 \% \\
\text { FC }\end{array}$} & Control & $75.63 \pm 0.57 \mathrm{a}$ & $15.34 \pm 0.64 \mathrm{c}$ & $3.22 \pm 0.12 b$ & $17.57 \pm 0.31 \mathrm{~d}$ \\
\hline & $0.2 \mathrm{mM}$ BABA & $74.65 \pm 0.52 \mathrm{a}$ & $17.45 \pm 0.62 b$ & $3.46 \pm 0.12 \mathrm{a}$ & $19.25 \pm 0.12 \mathrm{c}$ \\
\hline & $0.4 \mathrm{mM}$ BABA & $74.83 \pm 0.49 \mathrm{a}$ & $18.74 \pm 0.59 \mathrm{a}$ & $3.48 \pm 0.12 \mathrm{a}$ & $21.76 \pm 0.12 b$ \\
\hline & $0.2 \mathrm{mM} \mathrm{Spd}$ & $75.18 \pm 0.54 a$ & $17.56 \pm 0.61 \mathrm{~b}$ & $3.44 \pm 0.12 \mathrm{a}$ & $20.83 \pm 0.12 b$ \\
\hline & $0.4 \mathrm{mM} \mathrm{Spd}$ & $74.72 \pm 0.53 \mathrm{a}$ & $19.88 \pm 0.63 \mathrm{a}$ & $3.53 \pm 0.12 \mathrm{a}$ & $23.49 \pm 0.12 \mathrm{a}$ \\
\hline \multirow{5}{*}{$\begin{array}{c}50 \% \\
\text { FC }\end{array}$} & Control & $69.33 \pm 0.45 c$ & $9.56 \pm 0.47 f$ & $1.87 \pm 0.12 \mathrm{~g}$ & $10.27 \pm 0.12 \mathrm{~g}$ \\
\hline & $0.2 \mathrm{mM}$ BABA & $72.67 \pm 0.47 \mathrm{~b}$ & $11.43 \pm 0.45 \mathrm{e}$ & $2.11 \pm 0.12 \mathrm{f}$ & $13.64 \pm 0.12 f$ \\
\hline & $0.4 \mathrm{mM}$ BABA & $72.86 \pm 0.50 \mathrm{~b}$ & $11.76 \pm 0.49 \mathrm{e}$ & $2.54 \pm 0.12 \mathrm{~d}$ & $15.88 \pm 0.12 \mathrm{e}$ \\
\hline & $0.2 \mathrm{mM} \mathrm{Spd}$ & $72.55 \pm 0.44 b$ & $13.84 \pm 0.44 d$ & $2.38 \pm 0.12 \mathrm{e}$ & $13.79 \pm 0.12 \mathrm{f}$ \\
\hline & $0.4 \mathrm{mM} \mathrm{Spd}$ & $72.83 \pm 0.51 b$ & $13.19 \pm 0.47 \mathrm{~d}$ & $2.87 \pm 0.12 \mathrm{c}$ & $16.19 \pm 0.12 \mathrm{e}$ \\
\hline
\end{tabular}

The values (mean \pm S.E.) are the average of two independent experiments $(n=8)$. Means within a column had different letters are significantly differ for each other according to Tukey-Kramer's multiple range test at $P=0.05$.

A

B
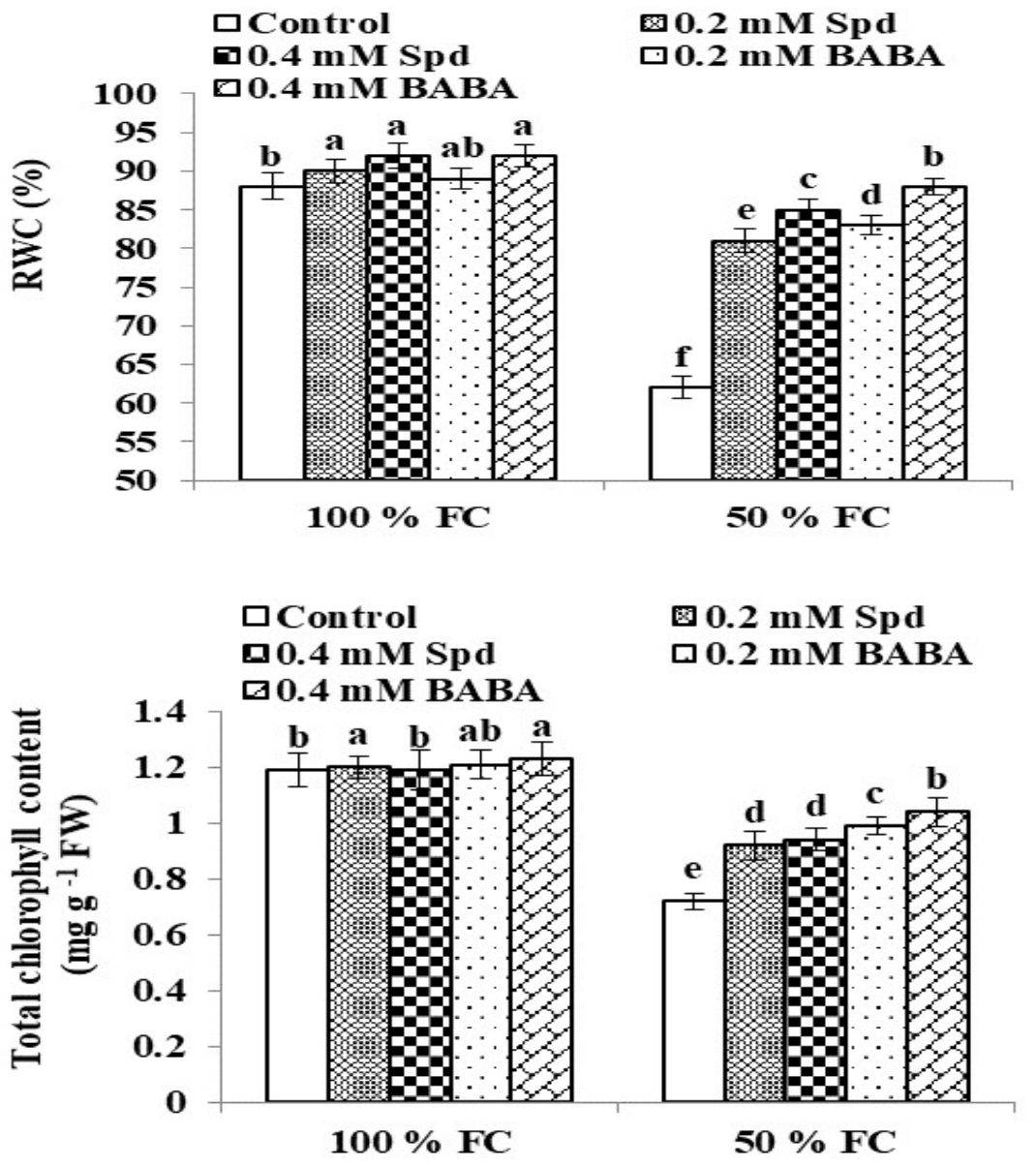

Fig. 1: Effects of foliar application with $\beta$-aminobutyric acid (BABA) and spermidine (Spd) on relative water content (A) and total chlorophyll content (B) of potted chrysanthemum grown under $100 \%$ FC or $50 \%$ FC. The values (mean \pm S.E.) are the average of two independent experiments $(n=8)$. Columns had different letters are significantly differ for each other according to Tukey-Kramer's multiple range test at $P=0.05$. 


\section{Proline content}

Proline content of potted chrysanthemum leaves was markedly increased in water stressed plants (50 $\%$ FC) compared to $100 \%$ FC water level. Both BABA and Spd treatments accumulated more proline under stress relative to non-stressed plants more so by applying Spd treatment (Fig. 2A). Under $100 \%$ FC, BABA or Spd application had no impact on proline content compared to the control.

\section{Malondialdehyde content (MDA)}

The MDA accumulation in potted chrysanthemum leaves was slightly reduced under well-watered condition due to BABA or Spd treatments compared to the control. However, the MDA accumulation was significantly increased in water stressed (50\% FC) plants relative to BABA or Spd treated plants. The lowest MDA content was recorded when Spd was applied (Fig. 2B).

Hydrogen peroxide $\left(\mathrm{H}_{2} \mathrm{O}_{2}\right)$ content

The water stress treatment significantly increased the $\mathrm{H}_{2} \mathrm{O}_{2}$ content compared to wellwatered plants. Even under $100 \% \mathrm{FC}$, applying of BABA or Spd reduced the $\mathrm{H}_{2} \mathrm{O}_{2}$ production relative to the control. However, a considerable reduction in
$\mathrm{H}_{2} \mathrm{O}_{2}$ was observed when BABA or Spd were used in water stressed plants. The treatment of Spd at 0.4 $\mathrm{mM}$ resulted in the lowest $\mathrm{H}_{2} \mathrm{O}_{2}$ level relative to the other treatments (Fig. 3A).

Membrane stability index (MSI)

Data presented in Fig. (3B) clearly indicate that drought stress significantly decreased MSI in potted chrysanthemum leaves compared to well-watered treatment. Application of BABA or Spd significantly improved MSI even under $100 \%$ FC treatment but the improvement was clearly observed under $50 \% \mathrm{FC}$ water level. The best treatment in this concern was Spd at $0.4 \mathrm{mM}$.

Catalase and Peroxidase enzyme activity

Drought stressed potted chrysanthemum showed higher CAT and SOD enzyme activities compared to $100 \%$ FC treatment. Additionally, foliar application with BABA or Spd under stress (50\% FC) significantly increased the activity of both enzymes relative to untreated plants however, under $100 \%$ FC treatment there were no differences were observed (Fig. 3B). The highest enzyme activitiy was observed in stressed plants and sprayed with Spd at $0.4 \mathrm{mM}$.

A
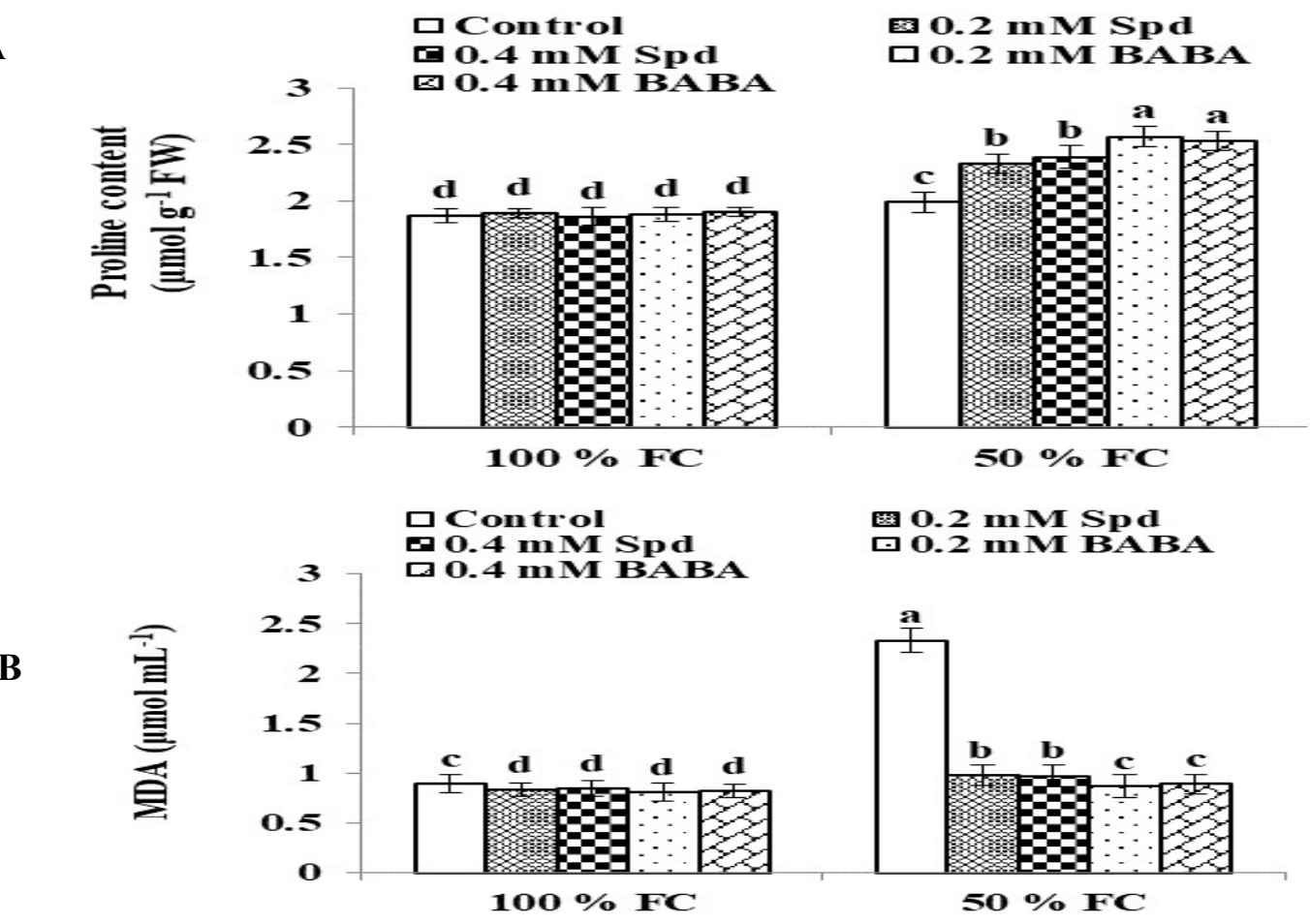

Fig. 2: Effects of foliar application with $\beta$-aminobutyric acid (BABA) and spermidine (Spd) on proline content (A) and malondialdehyde (MDA) content (B) of potted chrysanthemum grown under 100 $\%$ FC or $50 \%$ FC. The values (mean \pm S.E.) are the average of two independent experiments $(n=$ 8). Columns had different letters are significantly differ for each other according to TukeyKramer's multiple range test at $\boldsymbol{P}=0.05$. 


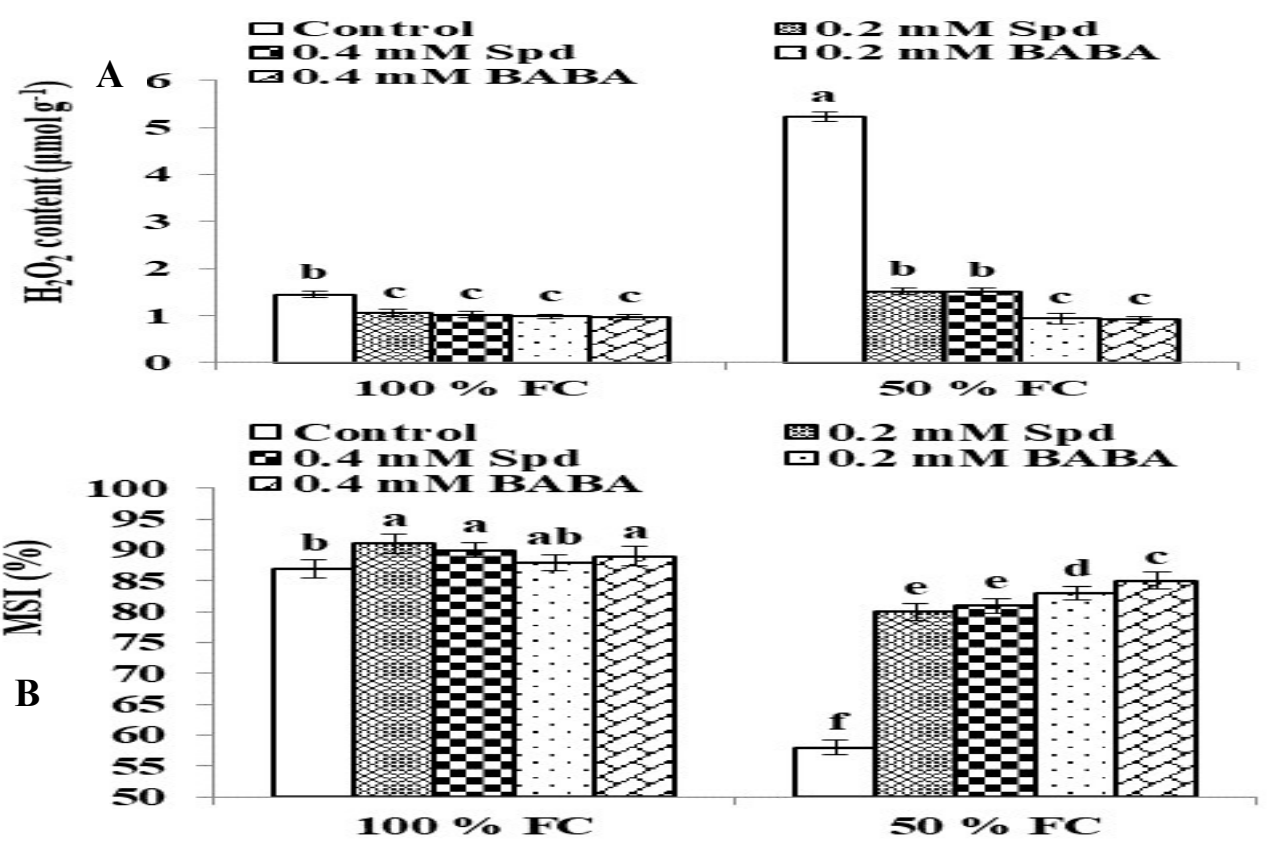

Fig. 3: Effects of foliar application with $\beta$-aminobutyric acid (BABA) and spermidine (Spd) on $\mathrm{H}_{2} \mathrm{O}_{2}$ content (A) and MSI (B) of potted chrysanthemum grown under $100 \%$ FC or $50 \%$ FC. The values (mean \pm S.E.) are the average of two independent experiments $(n=8)$. Columns had different letters are significantly differ for each other according to Tukey-Kramer's multiple range test at $P=0.05$.

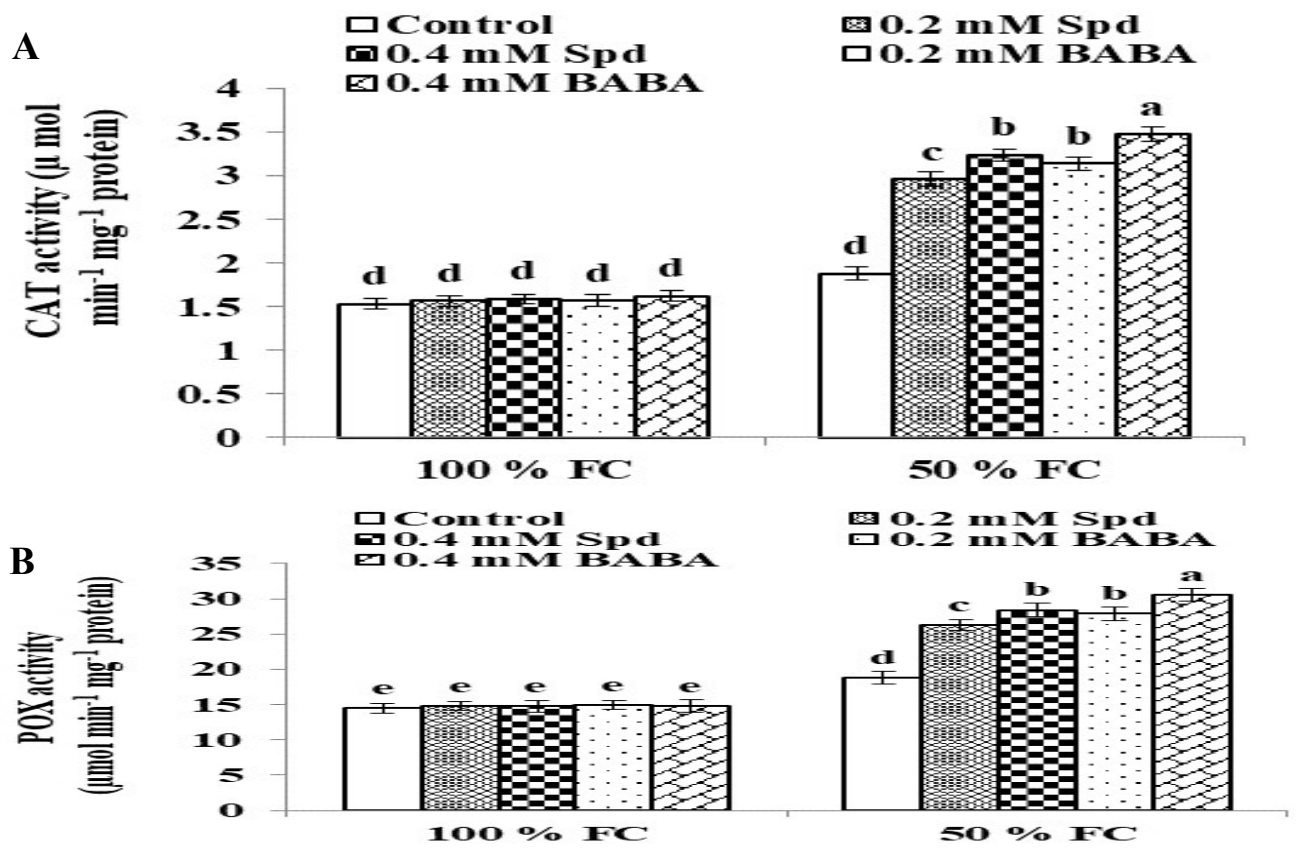

Fig. 4: Effects of foliar application with $\beta$-aminobutyric acid (BABA) and spermidine (Spd) on catalase (A) and peroxidase (B) enzyme activity of potted chrysanthemum grown under $100 \%$ FC or $50 \%$ FC. The values (mean \pm S.E.) are the average of two independent experiments $(n=8)$. Columns had different letters are significantly differ for each other according to Tukey-Kramer's multiple range test at $P=0.05$. 


\section{DISCUSSION}

This study focused on the impact of BABA and Spd on drought tolerance in potted chrysanthemum. The results of current study illustrated that the growth characters of potted chrysanthemum (plant height, branch number, stem diameter and leaf area) were considerably decreased under stress compared to well-watered treatment. These results are in accordance with the results of Talaat et al. (2015) and Hassan et al. (2018). Otherwise, foliar application with BABA or Spd alleviated the adverse effects of drought and improved the growth of potted chrysanthemum. Application of BABA plays a critical role in enhancing plant tolerance versus different abiotic stresses (Zhong et al., 2014, Quéro et al., 2015 and Ali and Hassan, 2019). In the same direction, the growth of water stressed rose was enhanced due to Spd application (Hassan et al., 2018). In the same direction of vegetative growth, the flower characters of potted chrysanthemum were considerably enhanced when BABA or Spd were applied under water stress conditions. Increasing the growth may reflected in improving the flower characters. The number of opened flowers affect the potted chrysanthemum shelf life therefore, increasing number of flowers may be a reason of increasing the shelf life of whole plant. These results are in accordance with the report of Ali and Hassan (2016) on potted chrysanthemum. Otherwise, the flowering was earlier in water stressed plants relative to well-waterd ones. It has been reported that, drought stress can be easily induced by irrigation control and hence drought stress could induce flowering and enhance carbohydrate accumulation (Pingping et al., 2017).

Tissues dehydration under drought could be evaluated by RWC that is signal the cell water status. In current study, a reduction in RWC was observed in drought-stressed plants however, this reduction was notably retarded in potted chrysanthemum by BABA or Spd applications. Additionally, the chlorophyll content goes in parallel with water status in leaves. Maintaining the RWC and chlorophyll under stresses due to BABA treatment has been reported (Jisha \& Puthur, 2016 and Ali and Hassan, 2019). Otherwise, the mesophyll cells water status is improved due to Spd treatment (Farooq et al., 2009) and hence the photosynthesis may be enhanced (Hassan et al., 2018). Maintaining RWC and chlorophyll in stressed plants due to Spd application has been observed (Li et al., 2015).

The proline level was increased under drought stress and the applications of BABA or Spd increased the proline content in potted chrysanthemum under stress. Ashraf and Harris (2004) found that proline plays an adaptive role in plants grown under environmental stresses to mediate osmotic adjustment and preserve the subcellular structures. Moreover, proline also detoxifies cells through ROS scavenging (Kamiab et al., 2014) and therefore its accumulation could protect cells against oxidative damage (Olga et al., 2003). In accordance with our results, Quéro et al. (2015), Das et al. (2016) observed an accumulation of proline due to BABA treatment under stress. Furthermore, several reports show the increasing of proline due to polyamines including Spd treatment under stresses (Farooq et al., 2009, Kubis' et al., 2014 and Hassan et al., 2018).

Drought stressed potted chrysanthemum exposed to showed higher MDA and $\mathrm{H}_{2} \mathrm{O}_{2}$ contents compared to well-watered plants. Meanwhile, BABA or Spd treatments decreased the MDA and $\mathrm{H}_{2} \mathrm{O}_{2}$ under stress and therefore retained the membrane integrity under drought. Farooq et al. (2009) reported that, under water deficit, MDA is a lipid peroxidation indicator of oxidative stress. These results support the other reports of Jisha and Puthur (2016) and Ali and Hassan (2019) who observed an increase in both MDA and $\mathrm{H}_{2} \mathrm{O}_{2}$ contents in stressed plants however, BABA application retarded that increase and maintained the membrane integrity. Accumulation of ROS deteriorates cell membrane and harms proteins and lipids that finally caused cell death (Miller et al., 2010). Additionally, Spd application could protect the membrane integrity and alleviates the membrane damage in stressed plants through scavenging the free radicals (Zhao and Yang, 2008 and Hassan et al., 2018).

In this experiment, the activities of CAT and POX enzymes were increased in potted chrysanthemum under drought by applying BABA or Spd relative to the control. Motivating the system of antioxidant is important to mitigate the oxidative stress (Li et al., 2015) as effective ROS scavengers (Foyer and Fletcher, 2001). In agreement of our results, Das et al. (2016) and Jisha and Puthur (2016) recorded an activation in antioxidant enzymes due to BABA treatment under stress condition. In the same direction, Spd treatment increased the antioxidant enzyme activity in water stressed damask rose (Hassan et al., 2018). Moreover, motivating the system of antioxidant as a result of Spd application and therefore increasing the capacity of ROS scavenging have been documented (Farooq et al., 2009 and Li et al., 2015).

\section{CONCLUSIONS}

Conclusively, the impact of exogenously applied BABA or Spd in drought tolerance of potted chrysanthemum was investigated. The plant growth, flower characters, RWC and chlorophyll were reduced under drought, while BABA or Spd treatments markedly alleviated the adverse effects of drought and improved the growth and developmnt 
in stressed plants. Additionally, BABA or Spd applications increased the proline content, decreased MDA and $\mathrm{H}_{2} \mathrm{O}_{2}$ contents and therefore retained the membrane integrity under drought. Potted chrysanthemum grown under drought showed higher activities in CAT and POX enzymes when BABA or Spd were applied. Application with BABA or Spd are suggested to play critical roles in adaptation of drought stressed potted chrysanthemum plants.

\section{ACKNOWLEDGEMENT}

The author gratefully acknowledge Prof. Dr. Hassan F.A.S. for helping and critical revision of this manuscript.

\section{REFERENCES}

Ali, E. and Hassan, F. (2017) Water stress alleviation of roselle plant by silicon treatment through some physiological and biochemical responses. Annual Research \& Review in Biology, 21 (3), 1-17.

Ali, E. F. and Hassan, F. (2016) Supplemental effects of silicon nutrition on growth, quality and some physiological characters of potted chrysanthemum grown in greenhouse. Acta Scientiarum Polonorum Hortorum Cultus, 15 (4), 85-98.

Ali, E. F. and Hassan, F. A. S. (2019) $\beta-$ Aminobutyric acid raises salt tolerance and reorganizes some physiological characters in Calendula officinalis L. plant. Annual Research \& Review in Biology, 30 (5), 1-16.

Arbona, V. and Gómez-Cadenas, A. (2008) Hormonal modulation of citrus responses to flooding. Journal of Plant Growth Regulation, 27, 241-250.

Ashraf, M. and Harris, P.J.C. (2004) Potential biochemical indicators of salinity tolerance in plants. Plant Science, 166, 3-16.

Bates, L.S., Waldren, R.P. and Teare, I.D. (1973) Rapid determination of free proline for waterstress studies. Plant Soil, 39, 205-207.

Bradford, M.M. (1976) A rapid and sensitive method for quantitation of micro quantities of protein utilizing the principle of protein-dye binding. Analytical Biochemistry, 72, 248258.

Clairbone, A. (1985) Catalase activity. In: R.Greenwald (ed.). Handbook of methods for oxygen radical research. CRC Press, Boca Raton, Fla. pp. 283-284.

Das, A., Ray, R., Mandal, N. and Chakrabarti, K. (2016) An analysis of transcripts and enzyme profiles in drought stressed jute (Corchorus capsularis) and rice (Oryza sativa) seedlings treated with $\mathrm{CaCl}_{2}$, hydroxyapatite nanoparticle and $\beta$-amino butyric acid. Journal of Plant Growth Regulation 79, 401.
Farooq, M., Wahid A.and Lee D. (2009) Exogenously applied polyamines increase drought tolerance of rice by improving leaf water status, photosynthesis and membrane properties. Acta Physiologiae Plantarum, 31, 937-945.

Foyer, C.H. and Fletcher, J.M. (2001) Plant antioxidants: colour me healthy. Biologist 48, 115-120.

Groppa, M.D. and Benavides, M.P. (2008) Polyamines and abiotic stress: recent advances. Amino Acids, 34, 35-45.

Hassan, F. and Schmidt, G. (2004) Postharvest features of chrysanthemum cut flowers as affected by different chemicals. International Journal of Horticultural Science, 10 (1), 127 131.

Hassan, F., Ali, E. and Alamer, K. (2018) Exogenous application of polyamines alleviates water stress-induced oxidative stress of Rosa damascena Miller var. trigintipetala Dieck. South African Journal of Botany, 116, 96-102.

Hodges, D.M., Delong, J.M., Forney, C.F. and Prange, R.K. (1999) Improving the thiobarbituric acidreactive-substances assay for estimating lipid peroxidation in plant tissue containing anthocyanin and other interfering compounds. Planta, 207, 604-611.

Jisha, K.C. and Puthur, J.T. (2016) Seed priming with BABA ( $\beta$-amino butyric acid): a costeffective method of abiotic stress tolerance in Vigna radiata (L.) Wilczek. Protoplasma, 253, 277-289.

Kamiab, F., Talaie A., Khezri, M. and Javanshah, A. (2014) Exogenous applications of free polyamines enhance salt tolerance of pistachio (Pistacia vera L.) seedlings. Plant Growth Regulation, 72, 257-268.

Kubis', J. (2008) Exogenous spermidine alters in different ways activities of some scavenging system enzymes, $\mathrm{H}_{2} \mathrm{O}_{2}$ and superoxide radical levels in water stressed cucumber leaves. Journal of Plant Physiology, 165, 397-406.

Kubis', J., Floryszak-Wieczorek J. and Arasimowicz-Jelonek, M. (2014) Polyamines induce adaptive responses in water deficit stressed cucumber roots. Journal of Plant Research, 127, 151-158.

Li, Z., Zhou H., Peng Y., Zhang X., Ma X., Huang L. and Yan Y. (2015) Exogenously applied spermidine improves drought tolerance in creeping bentgrass associated with changes in antioxidant defense, endogenous polyamines and phytohormones. Plant Growth Regulation, 76, 71-82. 
Marcinska, I., Czyczyło-Mysza, I., Skrzypek, E., Filek, M., Grzesiak, S., Grzesiak, M.T., Janowiak, F., Hura, T., Dziurka, M., Dziurka, K., Nowakowska, A. and Quarrie, S.A. (2013) Impact of osmotic stress on physiological and biochemical characteristics in drought susceptible and drought resistant wheat genotypes. Acta Physiologiae Plantarum, 35, 451-461.

Martin-Tanguy, J. (2001) Metabolism and function of polyamines in plants: recent development (new approaches). Plant Growth Regulation, 34, 135-148.

Matthew, E.O., Douglas, A.L., Isaacs, R., (2002) An inexpensive accurate method for measuring leaf area and defoliation through digital image analysis. Journal of Economic Entomology, 95 (6), 1190-1194.

Mayer, A., Eskandari, S., Grallath, S. and Rentsch, D. (2006) AtGAT1, a high affinity transporter for $\gamma$-aminobutyric acid in Arabidopsis thaliana. Journal of Biological Chemistry, 281, 7197-7204.

Metzner, H., Rau, H. and Senger, H. (1965) Unter suchungen zur synchronisier barteit einzelner pigmentan angel mutanten von chlorela. Planta, 65, 186.

Miller, G., Suzuki, N., Ciftci-Yilmaz, S. and Mittler, R. (2010) Reactive oxygen species homeostasis and signalling during drought and salinity stresses. Plant, Cell \& Environment, 33, 453-467.

Olga, B., Eija, V. and Kurt, V.F. (2003) Antioxidants, oxidative damage and oxygen deprivation stress: a review. Annals of Botany, 91,179-194.

Patterson, B.D., Macrae, E.A. and Ferguson, I.B. (1984) Estimation of hydrogen peroxide in plant extracts using titanium (IV). Analytical Chemistry, 134, 487-492.

Pingping, W., Chubin, W., Biyan, Z. (2017). Drought Stress Induces Flowering and Enhances Carbohydrate Accumulation in Averrhoa Carambola. Horticultural Plant Journal, 3 (2): 60-66.

Pottosin, I., Velarde-Buendía, A.M., Bose, J., Zepeda-Jazo, I., Shabala, S. and Dobrovinskaya, O. (2014) Cross-talk between reactive oxygen species and polyamines in regulation of ion transport across the plasma membrane: implications for plant adaptive responses. Journal of Experimental Botany, 65, 1271-1283.
Quéro, A., Fliniaux, O., Elboutachfaiti, R., Petit, E., Guillot, X., Hawkins, S., Courtois J. and Mesnardr, F. (2015) $\beta$-Aminobutyric acid increases drought tolerance and reorganizes solute content and water homeostasis in flax (Linum usitatissimum). Metabolomics, 11: 1363.

Roychoudhury, A., Basu, S. and Sengupta, D.N. (2011) Amelioration of salinity stress by exogenously applied spermidine or spermine in three varieties of indica rice differing in their level of salt tolerance. Journal of Plant Physiology, 168, 317-328.

Sairam, R.K., Deshmukh, P.S. and Shukla, D.S. (1997) Tolerance to drought and temperature stress in relation to increased antioxidant enzyme activity in wheat. Journal of Agronomy and Crop Science, 178, 171-177.

Sánchez-Rodríguez, E., Romero, L. and Ruiz, J.M. (2016) Accumulation of free polyamines enhances the antioxidant response in fruits of grafted tomato plants under water stress Journal of Plant Physiology, 190, 72-78.

Shanon, L., Kay, E. and Lew, J. (1966) Peroxidase isozymes from horseradish roots. I. Isolation and physical properties. Journal of Biological Chemistry, 241, 2166.

Snedecor, G.W. and Cochran, W.G. (1980) Statistical Methods, seventh ed. Iowa State University Press, Ames, IA, USA.

Takahashi, T. and Kakehi, J.I. (2009) Polyamines: ubiquitous polycations with unique roles in growth and stress responses. Annals of Botany, 105, 1-6.

Talaat, N.B., Shawky, B.T. and Ibrahim, A.S. (2015) Alleviation of drought-induced oxidative stress in maize (Zea mays L.) plants by dual application of 24-epibrassinolide and spermine. Environmental and Experimental Botany, 113, 47-58.

Vijayakumari, K., Jisha, K.C. and Puthur, J.T. (2016) GABA/BABA priming: a means for enhancing abiotic stress tolerance potential of plants with less energy investments on defence cache. Acta Physiologiae Plantarum, 38, 230.

Weatherley, P.E. (1950) Studies in the water relations of the cotton plant. 1 . The field measurements of water deficit in leaves. New phytology, 49, 8 .

Xu, X., Shi, G., Ding, C., Xu, Y., Zhao, J., Yang, H. and Pan, Q. (2011) Regulation of exogenous spermidine on the reactive oxygen species level and polyamine metabolism in Alternanthera philoxeroides (Mart.) Griseb under copper stress. Plant Growth Regulation, 63, 251-258. 
Yang, J., Zhang, J., Liu, K., Wang, Z. and Liu, L. (2007) Involvement of polyamines in the drought resistance of rice. Journal of Experimental Botany, 58,1545-1555.

Zhao, H.Z. and Yang, H.Q. (2008) Exogenous polyamines alleviate the lipid peroxidation induced by cadmium chloride stress in Malus hupehensis Rehd. Scientia Horticulturae, 116, 442-447.
Zhong, Y.P., Wang, B., Yan, J.H., Cheng, L.J., Yao, L.M., Xiao, L. and Wu, T.L. (2014) DL- $\beta$ amino butyric acid induced resistance in soybean against Aphis glycines Matsumura (Hemiptera: Aphididae). PLOS One, 9(1), 111 .

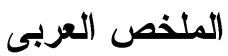

\title{
المعاملة بييتا أمينو بيوتيريك أسد واسبيرميدين تزيد تحمل الجفاف وتخفف من اجهاد الأكسدة في

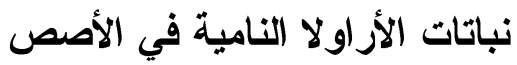

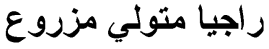 \\ قسم البساتين - كلية الزراعة - جامعة المنوفية مزية
}

تعتبر أزهار الأزاو لا النامية فى الاصص محصول زهرى مهم بسبب قيمته الاقتصادية كنبات زينـة تجـارى نئس

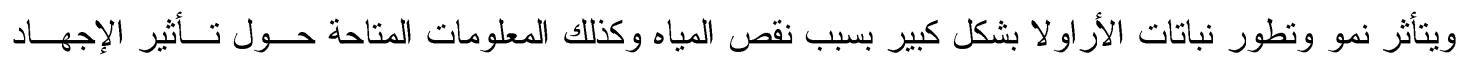

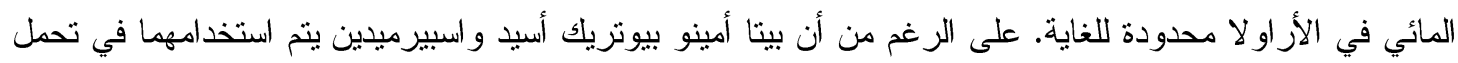

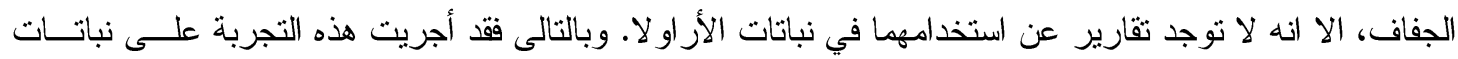

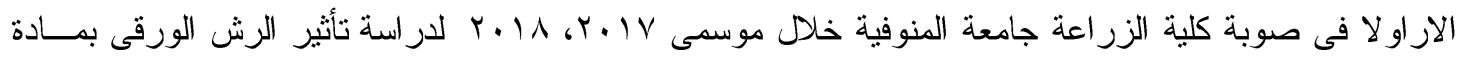

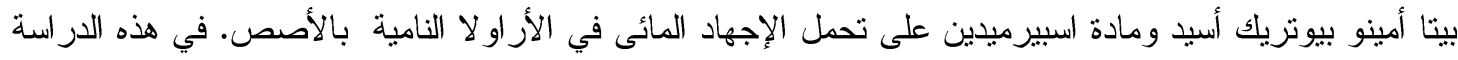

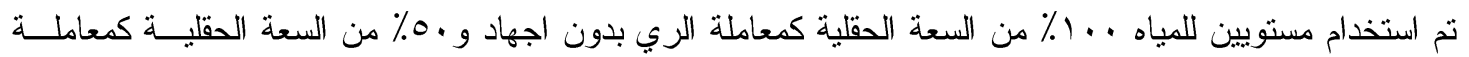

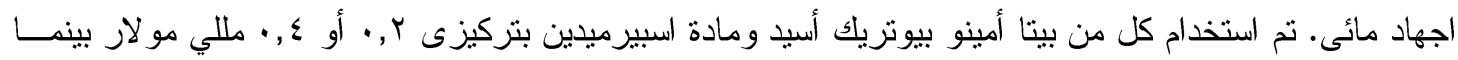

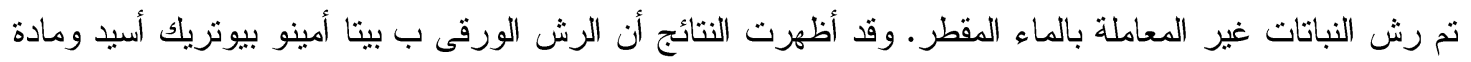

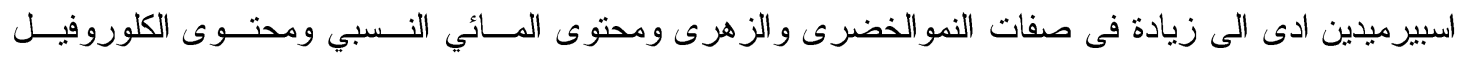

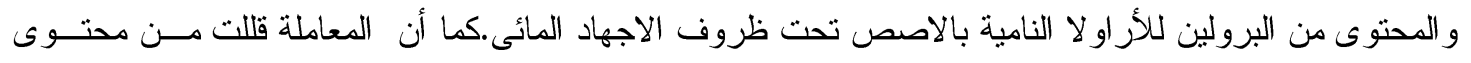

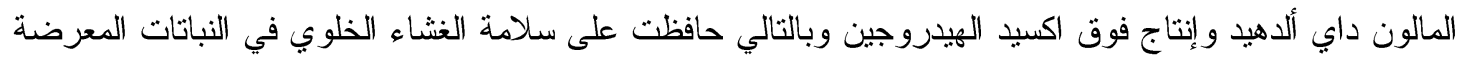

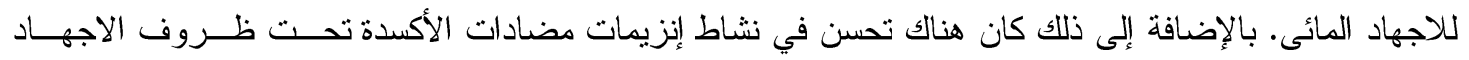

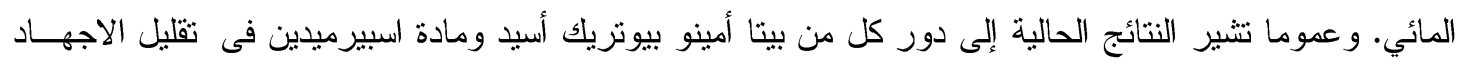

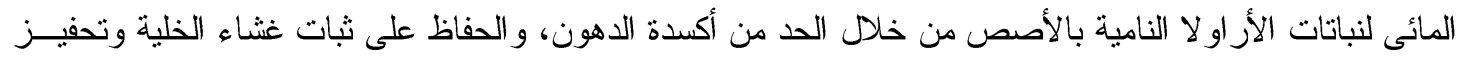

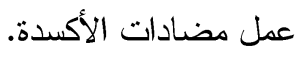

الكلمات المفتاحية: الجفاف، الكلوروفيل، البرولين، أكسدة الاهون، إنزيمات مضادات الأكسدة. 